\title{
THE ISSUE OF REPRESENTATIVENESS IN THE LIGHTS OF THE AMENDED TRADE UNIONS ACT
}

\begin{abstract}
The subject of the deliberations are issues regarding the representativeness and size of workplace trade union organisations after the changes introduced in the Trade Unions Act in 2018. According to the obligatory provisions, the "representativeness" of a trade union organisation is traditionally conditional on its size, but not only the employees, but also other categories of the employed are taken into account. It is, inter alia, about persons providing work under a contract of mandate or a specific work contract and sole proprietors. By expanding the full rights of coalition onto persons performing work on the basis other than employment relationship, the legislator increased the percentage limits decisive in the matter of representativeness. At present, the representative trade union organisation above the workplace level is also an organisation uniting at least $15 \%$ of all people performing gainful work under the articles of association, not fewer, however, than 10,000 persons performing gainful work. It works similarly at the workplace level. With reference to workplace trade union organisations which belong to organisations above the workplace level which meet the criteria for representativeness as specified in the Social Dialogue Council Act, at least 8\% of the staff of the given employer is required. In the case of workplace trade union organisations which do not participate in such structures, the representativeness is conditional on uniting of at least $15 \%$ of persons performing gainful work for the given employer ( $7 \%$ and $10 \%$, respectively, were required earlier). Determining the number of the staff, the employees and persons providing gainful work under other bases being employed for at least 6 months before the commencement of negotiations or arrangements must be included. A significant novelty is the necessity to select a joint representation of the representative organisations at the workplace level that belong to the same Trade Union Federation or National Trade Union Confederation in matters regarding collective rights and interests of the persons performing gainful work.
\end{abstract}

Keywords: trade union, representativeness above the workplace level, representativeness at the workplace level, the size of the trade union.

\section{PROBLEMY REPREZENTATYWNOŚCI W ŚWIETLE ZNOWELIZOWANYCH PRZEPISÓW USTAWY O ZWIĄZKACH ZAWODOWYCH}

Streszczenie. Przedmiotem rozważań są kwestie dotyczące reprezentatywności oraz liczebności zakładowych organizacji związkowych po zmianach wprowadzonych w ustawie o związkach zawodowych w 2018 r. W świetle obowiązujących przepisów o „reprezentatywności” organizacji związkowej tradycyjnie decyduje jej liczebność, z tym zastrzeżeniem, że uwzględnia się nie tylko pracowników, ale także inne kategorie zatrudnionych. Chodzi tu o m.in. osoby świadczące

\footnotetext{
*University of Bialystok; i.sierocka@uwb.edu.pl
} 
pracę na podstawie na umowy zlecenia, umowy o dzieło, prowadzących jednoosobowo działalność gospodarczą. Rozszerzając pełne prawo koalicji na osoby wykonujące pracę na innej podstawie niż stosunek pracy, ustawodawca podwyższył limity procentowe decydujące o przymiocie reprezentatywności. Obecnie na szczeblu ponadzakładowym za reprezentatywną uznaje się m.in. ponadzakładową organizację związkową, która zrzesza co najmniej nie $10 \%$, ale $15 \%$ ogółu osób zatrudnionych objętych działaniem statutu, co powinno stanowić co najmniej 10000 osób wykonujących pracę zarobkową. Podobnie na szczeblu zakładowym. W odniesieniu do zakładowych organizacji związkowych, które należą do organizacji ponadzakładowych spełniających przesłanki reprezentatywności określone w ustawie o Radzie Dialogu Społecznego, wymaga się zrzeszania co najmniej $8 \%$ załogi danego pracodawcy. W przypadku zakładowych organizacji związkowych nieuczestniczących w tego rodzaju strukturach o uzyskaniu przymiotu reprezentatywności, decyduje zrzeszanie co najmniej $15 \%$ wykonujących pracę zarobkową na rzecz określonego pracodawcy (uprzednio przewidywano odpowiednio 7\% i 10\%). Przy ustalaniu liczebności załogi należy wliczać pracowników i osoby świadczące pracę zarobkową na innej podstawie nieprzerwanie przez okres 6 miesięcy przed podjęciem rokowań lub uzgodnień. Istotnym novum ustawy jest konieczność wyłonienia przez reprezentatywne organizacje zakładowe, które wchodzą one w skład tego samego zrzeszenia (federacji) związków zawodowych lub ogólnokrajowej organizacji międzyzwiązkowej (konfederacji) wspólnej reprezentacji w sprawach dotyczących zbiorowych praw i interesów osób wykonujących pracę zarobkową.

Słowa kluczowe: związek zawodowy, reprezentatywność na szczeblu ponadzakładowym, reprezentatywność na szczeblu zakładowym, liczebność związku zawodowego.

\section{INTRODUCTION}

The expansion in the Trade Unions Act of 23 May (Consolidated text: Journal of Laws of 2019, item 263, hereinafter as "TUA") of the full right of coalition to persons performing gainful work not under an employment relationship - being the result of the judgment of the Constitutional Court of Law of 2 June 2015 (K 1/13, Journal of Laws, item 791) - entailed the need for amendment also to other regulations on trade unions, including the issue of representativeness of trade unions.

The "representativeness" providing the trade union with a special position in the union structures has been seen as one of the principal rules of collective labour law for long. It is accepted that an organisation with certain properties, notably the number of certain categories of people united in it, deserves special treatment and use of prerogatives which other trade unions do not enjoy (Goździewicz 2000, 63; Lekston 2019, 141; Sanetra 1994, 234-235). Moreover, the representativeness is regarded as a collision principle which allows selection from among the operating trade union organisations an entity most predestined for special activities, to which other (non-representative) trade union organisations are not authorised (Hajn 2013, 84; Pliszkiewicz, Seweryński 1995, 3-4). This is, for instance, about the rights provided for in Art. 19, 20 of TUA. Bearing in mind that the representativeness allows breaking the impasse between competing trade union organisations, it is generally accepted in the field of international labour law as well (Świątkowski 2013, 100; Świątkowski 2014, 388; International Labour Office 2018, par. 1382). 
The "most representative organisations of employees" is discussed e.g. in the Constitution of the International Labour Organisation of 1919 (Journal of Laws of 1948, No. 43, item 308, as amended; art. 3.5), ILO convention no. 144 of 1976 on tripartite consultation in the scope of introducing international labour standards. ${ }^{1}$ It is underlined that the representativeness does not challenge the principle of equal treatment of trade union organisations provided that it is based on objective and predetermined criteria. This feature is also not in opposition to the principle of freedom of association (International Labour Office 2018, par. 515; par. 1351).

Further on, the deliberations will focus on the criteria of representativeness of trade union organisations above the workplace level and at the workplace level after the amendments to the Trade Unions Act of 2018 (Amendments introduced by the Act of 5 July on amendment to the Trade Unions Act and other statutes, Journal of Laws, item 1608).

\section{REPRESENTATIVENESS ABOVE THE WORKPLACE LEVEL}

Under Art. $25^{2}(1)$ of TUA, the following is the representative trade union organisation above the workplace level: 1) a representative trade union organisation above the workplace level under the Act of 24 July 2015 on Social Dialogue Council and other social dialogue institutions (Journal of Laws of 2015, item 1240, as amended; hereinafter "SDCA"); 2) an organisation uniting at least $15 \%$ of all people performing gainful work under the articles of association, not less, however, than 10,000 persons performing gainful work; or 3) an organisation uniting the highest number of people performing gainful work for whom a specific collective bargaining agreement above the workplace level is to be concluded. The content of the provided provisions evidently indicates that the "representativeness" of the trade union organisation is traditionally conditional on its size, but not only the employees, but also other categories of the employed are taken into account (Art. $1^{1}(1)$ of TUA). It is, inter alia, about persons providing work under a contract of mandate or a specific work contract and sole proprietors. However, the persons united in a trade union are excluded if they do not perform gainful work, particularly old-age pensioners, disability pensioners, the unemployed and volunteers. In the case of complex structures - federations and confederations - included should be not only persons directly united in the given trade union, but also persons belonging to trade union organisations being a member of the given structure (Sanetra 2011, 1264).

Invariably, under Art. $25^{2}$ of TUA two types of representativeness can be distinguished: general (absolute - points 1 and 2) and specific (special, relative

\footnotetext{
${ }^{1}$ http://www.mop.pl/doc/html/konwencje/k144.html [Accessed: 21 September 2019].
} 
- point 3). In the first case, representative organisations have an advantage over smaller (non-representative) organisations in relation to all rights in the sphere of collective labour law; in the latter case, a privileged position is ensured in the scope of an collective bargaining agreement above the workplace level. Therefore, selecting a representative organisation meeting this criterion requires exact determination of the addressees of a future collective bargaining agreement.

Under Art. 23(2) of SDCA, the name of the representative organisation is given to nationwide trade unions, nationwide associations (federations) of trade unions and nationwide inter-trade-union organisations (confederations) which unite more than 300,000 members being persons performing gainful work and which operate in national economy entities the basic objects of activity of which is specified in more than a half of the section of the Polish Classification of Activities as specified in the regulations on public statistics. When determining the criterion of size, no more than 100,000 members being persons performing gainful work who are persons performing gainful work in national economy entities the basic objects of activity of which is specified in one section of the Polish Classification of Activities as specified in the regulations on public statistics. A trade union organisation applying for classification as a representative organisation when determining the number of persons performing gainful work does not consider persons performing gainful work which are united in the member organisations which are - or were over the year before the submittal of an application for representativeness - united in a representative trade union organisation having representatives in the Council (section 3).

The feature of representativeness is also enjoyed by a trade union organisation above the workplace level, meeting jointly two conditions: it unites at least $15 \%$ of all employed covered by the articles of association, which is at least 10,000 persons performing gainful work (See decision of the Supreme Court of 8 October 1996 (I PRN 91/96, OSNP 1997, no. 8, item 132).

Features regarding the representativeness of trade union organisations above the workplace level have been modified to little extent prima facie. Along with the expansion of the right of coalition onto persons providing work under nonemployee employment relationships, the legislator accordingly increased the requirements regarding the size of a trade union organisation above the workplace level from $10 \%$ to $15 \%$ of all employed covered by the articles of association (Walczak 2018, 234; Szmit 2019, 28-29). Bearing in mind that the persons providing work under a contract of mandate or a specific work contract or sole proprietors are not interested in participation in trade union structures, increasing the requirements for the size of the trade union may lead to the organisations meeting the criteria for representativeness in 2019 will lose their privileged position. ${ }^{2}$ Without doubts, such concerns are not shared by the largest trade unions

${ }^{2}$ A drop of interest in a trade union membership has been observed in Poland for long. In 2018 over 1.5 million people were trade union members, by 16.6 thousands $(1.1 \%)$ less than in 
such as Independent Self-governing Trade Union "Solidarity", the All-Poland Alliance of Trade Unions (OPZZ) or the Trade Unions Forum (Masewicz 1993).

The representativeness of a trade union above the workplace level has to be found in court. Under Art. 25(1) of SDCA, the applications of nationwide trade union organisations for determination of representativeness are examined by the Regional Court in Warsaw, which issues a ruling in the matter within 30 days from the submittal of an application. Upon the lapse of 4 years from the ruling on determination of representativeness becoming final and non-appealable, a trade union organisation loses its rights of a representative organisation unless it proves to Presidium of the Council that it applied for determination of representativeness again. In such a case, the organisation keeps the status of a representative organisation until the court ruling on new determination of representativeness becomes final and non-appealable (Art. 25(3) of SDCA). Therefore, representative organisations are obliged to confirm its representativeness every 4 years. The period begins to run from the day on which the latest ruling in the matter becomes final and non-appealable.

Similarly to trade union organisations above the workplace level specified in $25^{2}(1)(2)$ and (3) of TUA, the ruling on determination of representativeness is issued within 30 days by the Regional Court in Warsaw in a non-contentious proceedings instigated upon application of the given trade union.

The determination of representativeness of a nationwide inter-trade-union organisation (confederation) is significant for the nationwide trade unions and associations (federations) of trade unions being its members. Member organisations become representative by operation of law, regardless of the number of persons performing gainful work united in those entities (Art. 252(3) of TUA).

\section{REPRESENTATIVENESS AT THE WORKPLACE LEVEL}

Under Art. $25^{3}$ (1) of TUA, the following is the representative trade union at the workplace level: 1) an organisation being an organisational unit or a member organisation of a trade union organisation above the workplace level regarded as representative under the Social Dialogue Council Act, which unites at least $8 \%$ persons performing gainful work under the employer; or 2) an organisation uniting at least $15 \%$ of persons performing gainful work under the employer. If none of the workplace trade union organisations meet the requirements specified in section 1, the representative workplace trade union organisation will be the organisation uniting the highest number of people who perform gainful work under the employer - section 2 (Wratny 2012).

2014, Social dialogue partners - organisations of employers and trade unions in 2018 (preliminary results), data compiled by Statistics Poland, https://stat.gov.pl/obszary-tematyczne/gospodarka-spoleczna-wolontariat/gospodarka-spoleczna-trzeci-sektor/partnerzy-dialogu-spolecznego-zwiazki-zawodowe-i-organizacje-pracodawcow-wyniki-wstepne,16,1.html [Accessed: 16 June 2020]. 
The feature of representativeness at the workplace level, as above the workplace level, is conditional solely on the membership count of the given trade union. With reference to workplace trade union organisations which belong to organisations above the workplace level which meet the criteria for representativeness as specified in the Social Dialogue Council Act, at least $8 \%$ of the staff of the given employer is required. In the case of workplace trade union organisations which do not participate in such structures, the representativeness is conditional on uniting of least $15 \%$ of persons performing gainful work for the given employer $(7 \%$ and $10 \%$, respectively, were required earlier). As in the case of representativeness above the workplace level, raising the requirements for size of a trade union organisation to $8 \%$ and $15 \%$ combined with no interest on the part of persons performing work under non-employee civil law employment can lead to many trade union organisations losing their representativeness.

In the literature, the criteria for representativeness -8 and $15 \%$ (previously 7 and $10 \%$ ) - evoke serious doubts as to whether they comply with the principle of equal treatment (Latos-Miłkowska 2007, 146; Rączka 2008, 882). The Constitutional Court of Law evaluates those regulations differently. In the judgment of 11 December 1996 (K 11/96, OTK-ZU 1996, no. 6, item 54), the Constitutional Court of Law found that the fulfilment of the constitutional principles of equality and social justice does not mean that it is necessary to grant the same rights and obligations to all categories of citizens (groups of entities). Individual categories of entities should be treated equally, i.e. according to the same measurement, without favouring and discriminating diversifications, only if the factual standing of those categories of entities underlies certain provisions of law. The Constitutional Court of Law expressed a similar opinion in the judgment of 23 October 2001 (K 22/01, OTK 2001, no. 7, item 215) deciding that the representativeness of a trade union is conditional not only on the percentage of the employees of the given workplace (currently employed), but also on its social profile and the number of represented employee groups. Trade unions united in larger structures above the workplace level integrate interests of various employee groups, including weaker professional groups, which cannot effectively defend their interests by way of independent action. The adopted criterion for representativeness at the workplace does not differentiate trade union organisations having a common feature. In consequence, the regulation in question does not impose unjustified differences.

When determining the number of persons performing gainful work who are members of a trade union, only those employed are considered who have belonged to the given trade union organisation for at least 6 months before the commencement of negotiations or arrangements (Art. $25^{3}(6)$ of TUA). In turn, when calculating the number of the employed, one that is the basis for calculation of said percentages, or when determining the highest number of persons performing gainful work employed at the employer's site, solely the employees are taken into consideration who have been employed by the given employer for at least 6 months 
before the commencement of negotiations or arrangements. The condition for at least 6 months of employment aims to prevent a trade union from becoming representative in the case of an organisation unites persons who - performing work under short-term civil law contracts - do not form strong bonds with the employer.

The provision of $25^{3}(6)$ sets forth a repetition of the principles previously provided for in $241^{25 a}(3)$ of the Labour Code, where it was specified that when counting employees united in a trade union, only employees belonging to the given trade union organisation for at least 6 months before the commencement of negotiations regarding the conclusion of a collective bargaining agreement. As in the revoked provision of the Labour Code, the size of a trade union organisation depended on the number of its members being in employment relationships, which by essence are characterised by continued nature, it needed to be assumed that it is about a continued period of 6 months before the commencement of negotiations. The Constitutional Court of Law expressed a similar opinion in the judgment of 23 October 2001 (K 22/01, OTK 2001, no. 7, item 215), where it was found that representative trade union organisations can include only such organisations which can prove certain stability in their size over a certain period of time. The capacity of trade unions to represent employee interests is conditional not only on the number of their members at the given time, but also on certain minimum stabilisation of the number of the associated employees. In particular, the feature of representativeness cannot be bestowed on a trade union organisation which has only transiently achieved the size required in the statutory law by way of intensive recruitment of new members in order to participate in negotiations.

Currently as well, despite the fact that Art. $25^{3}(6)$ of TUA does not contain an express provision in this respect, the size of a trade union organisation consider the members who have been united in it for at least 6 consecutive months before the commencement of negotiations or arrangements. A person performing gainful work who at the same time belongs to more than one workplace trade union organisation can be regarded as a member of only one of such organisations when calculating the size of them (Art. 251(5) of TUA).

Doubts arise as to the manner of calculation of the 6 months' period of employment before the commencement of negotiations or arrangements. According to M. Latos-Miłkowska, "the required period does not have to be continuous". However, it is required that the given person be employed directly before the commencement of negotiations or arrangements (Latos-Miłkowska $2019,31)$. In effect, it would be enough to employ a person who has worked under the given employer for the required period of 6 months a day before the commencement. A contrary opinion is held by M. Lekston, who claims that it is about a period of consecutive 6 months preceding the activities provided for in the statutory law (Lekston 2019, 154).

The Ratio legis of Art. 253(7) of TUA was to ensure the feature of representativeness to an organisation having an established and robust position 
in the given workplace, one is - therefore - particularly predestined for taking specific action in the area of individual and collective employment relationships. Bearing in mind the above circumstances, the latter stance should be agreed with and it should be assumed that when determining the size of the staff, only the employees and persons providing gainful work under other bases being employed for at least 6 months before the commencement of negotiations or arrangements.

In the eyes of $25^{3}$ of TUA, the representativeness of a workplace trade union organisation which can be classified as general at the workplace level - as a rule - is conditional on the number of the employees and persons performing gainful work under other basis being members of it. The proportions between those two categories of the employed do not matter. As a result, an organisation uniting e.g. $15 \%$ of contractors providing work for the benefit of the given employer is an equal partner of an organisation uniting $15 \%$ of the employees of the given employer. Special representativeness, allowing action on matters enumerated in Art. 30(6) of TUA, is tackled differently. Under the said provision, in the negotiations leading to determination, inter alia, the rules of remuneration, the rules of prizes, the rules of work, a representative organisation can be a trade union which meets the criteria specified in Art. $25^{3}(1)$ or (2) and which unites at least $5 \%$ of the employees under the employer. With references to autonomic sources of law, to the exclusion of collective bargaining agreements, the general representation as per $25^{3}(1)$ or (2) is supplemented by the requirement of uniting the proper number of employees. In consequence, a trade union covering over $15 \%$ of persons employed under the given employer, out of which the percentage with at least 6 months of seniority is less than $5 \%$ of the staff, is treated as a representative organisation once and on other occasions it does not use this feature. The differentiation of the legal status of a trade union organisation on the basis of the category of matters may in practice lead to a lot of doubts and commotion. The reservation as to the level of involvement of employees aim to prevent a situation where in negotiations regarding institutions tightly related to the labour market, notably the rules of remuneration, the rules of prizes and bonuses, the rule of the workplace social benefit fund, the annual leave plan or the rules of work, will be held by trade unions not representing the addressees of the above or representing them to little extent. Therefore, on this background serious reservations are evoked by the solutions adopted in the sphere of collective bargaining.

Under Art. 21(3) of TUA, the provisions on collective bargaining agreements apply accordingly to persons performing gainful work other than employees and to their employers as well as to organisations uniting those entities. The content of the quoted provision indicates that apart from collective bargaining agreements regulating the rights and obligations of employees and employers, there can be collective bargaining agreements covering persons remaining in non-employee civil law relations and hybrid collective bargaining agreements addressed to both categories of the employed. Omission in the regulations on collective bargaining 
agreements of minimum requirements for percentage participation of employees in trade union organisations enjoying the bargaining capacity may in practice lead to the situation where a collective bargaining agreement regulating the rights and obligations of the parties to the employment relationship is concluded by representative organisations uniting only persons providing work outside an employment relationship or with little participation of employees.

Of course, it might be that a collective bargaining agreement covering only persons providing work under civil law relations will be concluded by employee trade unions. In both situations, the content of a collective bargaining agreement will depend on the entities little interested in the scope of rights and obligations of the persons for whom the agreement is to be negotiated.

Under the provisions on representative organisations at the workplace level, a significant novelty is the necessity to select the joint representation in matters regarding collective rights and interests of the persons performing gainful work. Under the provision of $25^{3}(3)$ of TUA, the obligation in this respect rests with representative organisations as per section 1 point 1 if they are members of the same association (federation) of trade unions or a nationwide inter-trade-union organisation (confederation). If a joint representation is not selected, the feature of representativeness is enjoyed by the organisation with the highest number of the people employed under the given employer or the organisation uniting at least $15 \%$ of the staff (section 4). The latter is authorised to represent collective rights and obligations of the employed if two or more organisations belonging to the same federation (confederation) include the same percentage of the staff and, in consequence, it is not possible to determine the largest one. Therefore, it can happen that e.g. two federated organisations uniting $20 \%$ of the employed under the given employer each will lose the status of representativeness, which will be gained by a trade union uniting only $15 \%$ of the staff.

Negative effects in the form of losing the feature of representativeness pertain only to matters revolving around collective rights and obligations of the employed. These organisations keep the privileged position in other aspects, e.g. indication of persons covered by special protection (Art. 32(3) and (4) of TUA).

The requirement of creation of joint representation is, without doubt, dictated by the willingness to streamline negotiations concerning for instance autonomous legal acts. This is so as it eliminates the phenomenon of multiplication of trade unions. It must be stressed that the obligation of workplace trade union organisations being organisational entities or member organisations of trade union organisations above the workplace level regarded as representative as per SDCA to select a joint representation under pain of loss of representativeness undermines the principle of autonomy of trade unions and of freedom of negotiation.

As a rule, at the workplace level it is not required to determine the representativeness of the given trade union in court proceedings. Such proceedings become necessary if the employer or other trade union organisation raises 
objections as to the size of a trade union willing to guarantee itself a privileged position (Art. 251(7) of TUA). The time limit for pressing charges in this matter is 30 days from the time when the trade union provides information on its size. A workplace trade union organisation the popularity of which among the staff of the given workplace evokes doubts may: 1) before the district court - the labour court of proper venue serving the address of the employer: prove that it meets the criteria provided for in Art. $25^{3}(1)$ or (2) of TUA and so that it is fully legitimate to treat it in a privileged manner in terms of collective and individual labour law; or 2) "tacitly" acknowledge the stance of the entity challenging its representativeness. In the latter case, the organisation will be authorised to act in the area of collective rights and interests at the level equal to that of nonrepresentative trade union organisations. In effect, resignation from the judicial avenue leads to the loss of the feature of representativeness.

The court proceedings for determination of the number of members can also be instigated out of the own initiative of the workplace trade union organisation. In both situations, the court issues a ruling in the mode of non-contentious proceedings as per the Code of Civil Procedure within 60 days from the time of submittal of the application (Książek 2019, 137-139).

The mode of examination of the representativeness of the given trade union at the workplace level is convergent with the principles on the size of the workplace trade union organisation

\section{THE SIZE OF THE WORKPLACE TRADE UNION ORGANISATION}

Under $25^{1}(1)$ of TUA, the rights reserved for the workplace trade union organisation are enjoyed by an organisation uniting at least 10 members being: 1) employees under the employer covered by the operations of that organisation or 2) non-employees performing gainful work, who has performed work for at least 6 months for the employer covered by the operations of that organisation. Despite the fact that the legislator uses the expression of "or", it goes without doubt that both trade unions including only employees or only persons in civil law relations and organisations uniting persons with a diverse legal status can operate without any limitations. Bearing in mind that in the case of employees no requirements as to the time of employment in the given workplace are introduced, in a group of at least 10 members all trade union members remaining in an employment relationship with the given employer are taken into account. A situation is different in the case of persons performing work under non-employee civil law relations, who have to have worked at least 6 months in the given workplace. In Art. 251(1), the legislator yet again underscored the necessity of stronger bond between the employed and the employer, one which justifies including e.g. a contractor in the general number of members of the given trade union organisation. 
As a rule, a trade union organisation is obliged to present to the employer every 6 months - as at 30 June and 31 December - by the 10th day of the month following that period, information on the number of members meeting the criteria under Art. $25^{1}(1)$ of TUA. In the light of the regulations in effect, the size of a trade union organisation is verified twice a year. The size determined as at 30 June or 31 December is effective by the next verification even if the membership shrinks after that date. In this scope, fully topical is the stance of the Supreme Court specified in the judgment of 19 August 2015 (II PK 208/14, OSNP 2017, no. 7, item 82), where the concept that a drop of the number of members of a trade union below 10 person leads to the loss of the competences of the trade union organisation and protection of a trade union member right away was regarded as too strict and disproportionate to the effects and intentions of the legislator. Therefore, it was found that the legal functioning of a trade union is affected not by a short-term drop in the number of members, but by the size of a trade union organisation as at the end of a quarter (currently a half-year).

An organisation created during a 6-month period provides the first information on the number of members within 2 months from establishment and then - within the time limits effective for all other trade unions. A trade union organisation towards which the employer or another trade union raises reservations as to its size can assert its rights in court by the principles stipulated in Art. $25^{1}(8)$ of TUA.

\section{CONCLUSIONS}

By its essence, the expansion of the full right of coalition onto persons providing work under non-employee civil law relations had an impact on the criteria for representativeness of a trade union organisation, particularly at the workplace level. Raising the quantitative requirements may deprive many trade unions of the status of a representative organisation.

With reference o some categories of cases, particularly the rules of work and remuneration, the legislator requires fulfilment not only of criteria determining the representativeness of the given trade union, but also those referring to the number of employees. However, the level of involvement of the employees does not matter in negotiation of collective bargaining agreements. In effect, one cannot exclude a situation where a collective bargaining agreement defining the rights and obligations of parties to the employment relationship is negotiated by trade union organisations uniting mostly persons providing work under civil law contracts. The solutions adopted in this scope evoke serious doubts.

When determining the representativeness of a workplace trade union organisation, persons with a 6-month period of membership in the trade union and with proper seniority. The latter is also required from the hired persons who are 
not employees. The ratio legis of the adopted solutions is that they ensure rights in the sphere of collective and individual employment relationships to workplace trade union organisations with a rather stable membership.

\section{BIBLIOGRAPHY}

Freedom of Association. Compilation of Decisions of the Committee on Freedom of Association. 2018. Geneva: International Labour Office.

Goździewicz, Grzegorz. 2000. Ed. "Podstawowe zasady zbiorowego prawa pracy”. In Zbiorowe prawo pracy $w$ społecznej gospodarce rynkowej. Toruń: TNOiK.

Hajn, Zbigniew. 2013. Zbiorowe prawo pracy. Zarys systemu. Warszawa: Wolters Kluwer.

Książek, Daniel. 2019. In Zbiorowe prawo zatrudnienia. Komentarz. Edited by Krzysztof W. Baran. 137-139. Warszawa: Wolters Kluwer.

Latos-Miłkowska, Monika. 2007. "Reprezentatywność w zbiorowych i indywidualnych stosunkach pracy". In Zbiorowe a indywidualne prawo pracy. Edited by Ludwik Florek. 146. Warszawa: Wolters Kluwer.

Latos-Miłkowska, Monika. 2019. "Reprezentatywność zakładowych organizacji związkowych po nowelizacji ustawy o związkach zawodowych - nowa jakość czy stracona szansa?”. Praca i Zabezpieczenie Społeczne 5: 28-35.

Lekston, Mariusz. 2019. In Zbiorowe prawo zatrudnienia. Komentarz. Edited by Krzysztof W. Baran. 141-154. Warszawa: Wolters Kluwer.

Masewicz, Walery. 1993. "Reprezentatywność jako cecha związku zawodowego (na przykładzie NSSZ ‘Solidarność 80’)”. Praca i Zabezpieczenie Społeczne 5-6: 17-24.

Pliszkiewicz, Marek. Michał Seweryński. 1995. "Problemy reprezentatywności w zbiorowych stosunkach pracy". Państwo i Prawo 9: 3-4.

Rączka, Krzysztof. 2008. In Kodeks pracy. Komentarz. Edited by Małgorzata Gersdorf, Krzysztof Rączka, Jacek Skoczyński, Zbigniew Salwa. 882. Warszawa: Wydawnictwo Prawnicze LexisNexis.

Sanetra, Walerian. 1994. Prawo pracy. Białystok: Temida 2.

Sanetra, Walerian. Józef Iwulski. 2011. Eds. Kodeks pracy. Komentarz. Warszawa: Wydawnictwo Prawnicze LexisNexis.

Szmit, Jakub. 2019. "Reprezentatywność zakładowej organizacji związkowej w świetle nowelizacji ustawy o związkach zawodowych”. Praca i Zabezpieczenie Społeczne 3: 28-32.

Świątkowski, Andrzej M. 2013. “Obowiązek władz państwowych promowania rokowań w sprawie układów zbiorowych pracy". In Układy zbiorowe pracy. W stulecie urodzin Profesora Wacława Szuberta. Edited by Zbigniew Góral. 95-130. Warszawa: Lex a Wolters Kluwer business.

Świątkowski, Andrzej M. 2014. In System prawa pracy. T. V. Zbiorowe prawo pracy. Edited by Krzysztof W. Baran. Warszawa: Lex a Wolters Kluwer business.

Walczak, Krzysztof. 2018. "Pojęcie reprezentatywności związków zawodowych w świetle nowelizacji ustawy o związkach zawodowych”. Studia z Zakresu Prawa Pracy i Polityki Społecznej 3: 223-241.

Wratny, Jerzy. 2012. "Problem reprezentatywności związków zawodowych w zakładzie pracy. Więcej pragmatyzmu czy demokracji”. Praca i Zabezpieczenie Społeczne 3: 2-9. 